\title{
The Study of Teachers' General Cynicism Inclinations in Terms of Life Satisfaction and Other Variables
}

\author{
Hüseyin Aslan ${ }^{1}$, Ercan Yilmaz ${ }^{2}$ \\ ${ }^{1}$ Directorate of Education Inspectors, Sinop National Education Directorate, Sinop, Turkey \\ ${ }^{2}$ Faculty of Education, Selçuk University, Konya, Turkey \\ Email: huseyarslan@yahoo.com, ercanyilmaz70@gmail.com
}

Received July 19 $9^{\text {th }}, 2013$; revised August 19 $9^{\text {th }}, 2013$; accepted August $26^{\text {th }}, 2013$

\begin{abstract}
Copyright $@ 2013$ Hüseyin Aslan, Ercan Yilmaz. This is an open access article distributed under the Creative Commons Attribution License, which permits unrestricted use, distribution, and reproduction in any medium, provided the original work is properly cited.
\end{abstract}

\begin{abstract}
This research aims to examine teachers' general cynicism inclinations in respect to some variables and life satisfaction level and the relevance of these inclinations with gender, relationship status and membership of a union. Research is carried out using relational inquiry module and the study group of it constituted of 395 primary school teachers who are working in Ankara during academic year of 2012-2013 and selected with the help of modeling of inordinate set. The data are collected with "The Scale of Life Satisfaction" and tested by making use of multiple regression technique. Whether the differentiation levels of teachers' general cynicism inclinations are related with their genders, relationship status and their membership of a union are analyzed using $\mathrm{T}$ test. As a result, male teachers have higher degree of cynicism in cognitive dimension than female teachers. Moreover, these general cynicism inclinations in cognitive, affective and behavioral dimensions do not differ greatly according to teachers' membership of a union and relationship status. It is observed that the cognitive and affective dimensions of general cynicism inclinations have negative-sided relation with teachers' life satisfaction rates.
\end{abstract}

Keywords: The Cynicism Inclinations of Teachers; Teachers' Life Satisfaction

\section{Introduction}

Recently, various developments and structural renovations have started to gain importance in education process. The key factor to have healthy and smooth realization of this process is teachers. Teachers' general viewpoint of life may affect their performance at work. One of their viewpoints towards life is general cynicism inclinations.

General cynicism is a person's negative attitude against world. The person who always cares about his own stakes and considers everyone self seeking in this respect is called "cynic" and the system which tries to explain this kind of thought is named "cynicism" (Erdost, Karacaoğlu, \& Reyhanoğlu, 2007). In its simplest meaning, cynicism is the act of not liking and trusting others (Brandes et al., 2008). Person sees the world negatively and generalizes with false assumptions. In other words, cynicism is defined as clinical enmity and weakness in relationship between people. Accordingly, cynic has a deep disbelief towards others and corporations assuming the world is full of selfish and insecure people. Cynic thinks he is being treated unjustly and he has lost his confidence about system and others. He is jealous of colleagues and this behavior ends up with making fun of their success (Helvac1, 2010: p. 388). General cynicism is a negative viewpoint of the world seen in human race. This kind of thought system makes people think that life is unhappiness, corporations cannot be trusted and some abuse others (Tokgöz, 2011: p. 364). Cynics generally do not believe in others, and also consider them liar, dishonest, unsocial, immoral. (İnce \& Turan, 2011: p. 105). Cynicism is often misunderstood as skepticism (Helvac1, 2010: p. 386). However, these two concepts explain two different situations. There is no certainty in scepticism. In other words, there is as much probability of something happening as it may not in a doubtful situation. In contrast, there is absolute certainty in cynicism. Here, person has unchangeable degree of negative attitude towards people and corporations.

Life satisfaction, a psychological feature composed of people's viewpoints of life, expectations and their compensation levels, is expected to have impact on organizational aspect of work life. It is a situation in which a person compares what he wants and what he gets. It also expresses one's wellness according to happiness, morale etc. (Vara, 1999; Özer \& Karabulut, 2003).

Veenhoven (1996) defined life satisfaction as positive improvement degree of life quality as a whole. If it really means that the possibility of affecting someone's work life which is inseparable part of life and his loyalty to an organization must be thought. Christopher (1999) defined life satisfaction as a process in which someone compares quality of his life in terms of family, work, school and friendship areas with the criteria he has already formed about the standards of a good life.

Life satisfaction, thought as cognitive receptions and evaluations related with life as a whole (Yetim, 2001) falls into three parts. First one is the state of well being in which one compares his life with exterior criteria. Second one is a condition of faculty formed by someone judging his own life. Finally, third part is the condition of satisfaction occurring in the wake of daily relationships (Serin \& Özbulak, 2006). It is also considered 
important indicator of comprehensive happiness (Diener et al., 1986).

In a broad meaning, life satisfaction can be defined as one's emotional reaction to work life, and leisure time (Sung-Mook, 1994). People's life satisfaction may be affected by a lot of variables. Some of these are happiness in daily life, the meaning of life, harmony to reach goals, positive personal identity, social relationship, economical safety and person's well being physically (Schmitter, 2003).

Life satisfaction, a psychological feature which can affect all areas of daily life, is also important in terms of teaching profession because it is a job that requires relationship and interaction with a wide group of people (Sisman, 2000). Besides, another feature that makes it different from other jobs is its power of impression on people around. This puts psychological features of teachers forefront. Teacher's personal quality is a psychological power which affects students' cognitive, sensual and social development (Sünbül, 2002).

Educational organizations have a dynamic structure. Teachers, school managers and other workers' interests, life styles, attitudes, cultures, belief and moral systems, characteristics in the organization are affected by a lot of factors. In this sense, negative attitude consisting of behavioral inclinations occurs towards the organization. This attitude highlights cynicism resulting from both one's personal features and working conditions (Kalağan \& Güzeller, 2010).

To reach organizational culture and develop efficiency-centered new applications is dependent on teachers' attitude towards their own organization (Ercan, 2006). Vance, Brooks and Tesluk (1997) point out that if people have little faith in their organizations in terms of the probability of doing better, organizational cynicism will emerge (Kalağan \& Güzeller, 2010). As a result, teacher, having organizational cynicism, may feel that others ignore his struggle for the improvement in school conditions, stop giving advices for development, think that his advices are not taken into considerations and his actions remain unknown, believe that other teachers will not do their best to contribute to the process and nobody will get what he deserves but wrong person or behavior will be awarded in the end. Moreover, a cynic teacher may not believe that everything will be better and for him and he is hard to be hopeful about the future.

As it can be inferred from the explanations, teachers' personal characteristics and his psychological condition are very important concepts. Being one of the psychological conditions, life satisfaction can affect teachers' general cynicism inclinations. The aim of this research is to determine teachers' general cynicism inclinations according to their life satisfaction levels, membership of a union, relationship status and sex.

Questions to be answered at the end of the research are:

1) Do teachers' general cynicism inclinations vary according to their life satisfaction levels, membership of a union, relationship status and sex?

2) To what degree do teachers' life satisfaction levels explain cognitive, sensual and behavioral aspects of their general cynicism inclinations?

\section{Research Model}

The research has relational scanning model and tries to find out levels of teachers' life satisfaction and their speaking of loneliness in the workplace. At the same time, it aims to reveal the differentiation levels of their life satisfaction levels and loneliness in the workplace with regard to membership of a union, relationship status and sex.

\section{Research Group}

Research group consists of 395 primary and secondary school teachers in Ankara chosen with the help of concidential cluster sample method. There are 191 male and 203 female teachers in the study group. While $72 \%$ of them is married, the other $28 \%$ is single. Moreover, 164 of them are form tutors and 231 are teachers of different branches.

\section{Data Collection Tools}

\section{General Cynicism Scale}

In the study, the scale, developed by Wrightman and adapted into Turkish by Arslan (2012) is used in order to determine the level of general cynicism.

\section{Life Satisfaction Scale}

During the process of collecting data, Life Satisfaction Scale is used to determine the teachers' life satisfaction level. The Scale which was developed by Diener, Emmons, Larsen, Griffen (1995), adapted into Turkish by Köker (1991). Life Satisfaction Scale consists of five items, each of which is evaluated in terms of seven options. As a result of scale's accountability test, test-repeat-test accountability is found as $r=.85$ and itemtest correlation level is calculated between .71 and .80 .

\section{Cynicism}

\section{Analysis of Data}

The relationship between the extent of general cynicism tendency of teachers and their life satisfaction is tested with the Pearson product moment correlation coefficient method. The level of affection that the extent of general cynicism tendency of teachers has on life satisfaction is tested with Regression Technique. How much the general cynicism tendency of teachers differs according to their sexuality, marital status or whether they are a member of any syndicate is examined with $\mathrm{T}$ test. In education researches, level of meaning in analysis of data is mostly accepted as .05 (Balc1, 2004). For this reason, the accepted leve of meaning in this research is .05 'dir.

According to the results of T test as shown in the Table 1 below, (in the level of $p>.005$ ) it is understood that there is not a direct relationship between general cynicism tendency of teachers in terms of cognitive and behavioral level and the sexuality of participants. A large difference is observed in general cynicism tendency in terms of sensual level between male and female teachers. Cynicism tendency of male teachers is very high in comparison with females.

When the Table 2 below is examined, it can be inferred that average points of general cynicism inclinations do not differ greatly in cognitive, behavioral and sensual dimensions according to teachers' union membership variable.

Table 3 shows that average points of general cynicism inclinations do not differ greatly in cognitive, behavioral and sensual dimensions according to teachers' marital status variable.

Table 4 shows that there is meaningful but in a negative way 
Table 1.

The findings related to comparisons of life satisfaction of teachers and their general cynicism tendency according to their sexuality.

\begin{tabular}{|c|c|c|c|c|c|c|}
\hline \multirow{2}{*}{$\begin{array}{l}\text { GENERAL } \\
\text { CYNICISM }\end{array}$} & & & & & & \\
\hline & Sex & $\mathrm{N}$ & $\bar{X}$ & Ss & $\mathrm{t}$ & $p$ \\
\hline \multirow{2}{*}{ Cognitive } & M & 191 & 12.50 & 3.33 & \multirow{2}{*}{1.754} & \multirow{2}{*}{.050} \\
\hline & $\mathrm{F}$ & 203 & 11.92 & 3.24 & & \\
\hline \multirow{2}{*}{ Behavioral } & M & 191 & 8.51 & 2.39 & \multirow{2}{*}{.214} & \multirow{2}{*}{.831} \\
\hline & F & 203 & 8.46 & 2.24 & & \\
\hline \multirow{2}{*}{ Sensual } & M & 191 & 8.80 & 2.55 & \multirow{2}{*}{.730} & \multirow{2}{*}{.453} \\
\hline & $\mathrm{F}$ & 203 & 8.60 & 2.60 & & \\
\hline
\end{tabular}

Table 2.

The findings related to t-test comparison between general cynicism inclinations' sub-dimensions and life satisfaction points according to teachers' union membership variable.

\begin{tabular}{ccccccc}
\hline \multirow{2}{*}{ GENERAL } & & & & & & \\
\cline { 2 - 7 } CYNICISM & $\begin{array}{c}\text { Union } \\
\text { Membership }\end{array}$ & $\mathrm{N}$ & $\bar{x}$ & $\mathrm{Ss}$ & $\mathrm{t}$ & $p$ \\
\hline \multirow{2}{*}{ Cognitive } & Yes & 279 & 12.279 & 3.34 & .677 & .449 \\
& No & 115 & 12.03 & 3.19 & & \\
Behavioral & Yes & 279 & 8.53 & 2.36 & .805 & .422 \\
& No & 115 & 8.53 & 2.19 & & \\
Sensual & Yes & 279 & 8.67 & 2.58 & -.382 & .703 \\
& No & 115 & 8.77 & 2.53 & & \\
\hline
\end{tabular}

Table 3.

The findings related to t-test comparison between sub-dimensions of the loneliness in the workplace and life satisfaction points according to teachers' marital status variable.

\begin{tabular}{ccccccc}
\hline \multirow{2}{*}{ GENERAL } & \multicolumn{7}{c}{ CYNICISM } & Marital & $\mathrm{N}$ & $\bar{x}$ & $\mathrm{Ss}$ & $\mathrm{t}$ & $p$ \\
& Status & & & & & \\
\hline \multirow{2}{*}{ Cognitive } & Married & 286 & 12.24 & 3.343 & .327 & .744 \\
& Single & 109 & 12.12 & 3.19 & & \\
\multirow{2}{*}{ Behavioral } & Married & 286 & 8.46 & 2.25 & -.232 & .760 \\
& Single & 109 & 8.55 & 2.49 & & \\
Sensual & Married & 286 & 8.64 & 2.55 & -.696 & .487 \\
& Single & 109 & 8.85 & 2.65 & & \\
\hline
\end{tabular}

Table 4.

The correlation between teachers' life satisfaction levels and general cynicism inclinations' dimensions.

\begin{tabular}{cccc}
\hline \multirow{2}{*}{ GENERAL } & \multicolumn{3}{c}{ General Cynicism Dimensions } \\
\cline { 2 - 4 } CYNICISM & Cognitive & Behavioral & Sensual \\
\hline LIFE & $-.176^{* *}$ & -.018 & $.122^{*}$ \\
SATISFACTION & .000 & .720 & .014 \\
\hline${ }^{* *} p<.01 ;{ }^{*} p<.05$. & & &
\end{tabular}

corelation between life satisfaction points and conginitive, sensual dimensions of general cynicism inclinations. Hovewer, no meaningful correlation can be found between teachers' life satisfaction points and behavioral dimension points of general cynicism inclinations.

As shown in Table 5 teachers' life satisfaction explains only $3.1 \%$ of the variability in cognitive dimension of general cyni- cism inclinations.

According to Table 6, teachers' life satisfaction explains only $1.5 \%$ of the variability in sensual dimension of general cynicism inclinations.

\section{Discussion, Results and Advices}

According to findings, while there is not a direct relationship between general cynicism tendency of teachers in terms of cognitive and behavioral level and the sexuality of participants, a large difference is observed in general cynicism tendency in terms of sensual level between male and female teachers. Cynicism tendecy of male teachers is very high in comparasion with females. Cognitively, cynicism is the belief that individuals are bereaved of honesty and important morals. Men's having this kind of thought can be caused by the expectations. What are expected from men by the public are behaving independently, representing the family and being competitive (Temel \& Aksoy, 2001). Life may not present equal conditions to the individuals to make these expectations real. Therefore male teachers may have negative beliefs about life. According to Kanter and Mirvis (1991) it is found out that men are more sinic in comparison with women. Whether teachers are male or female does not affect sense of cynicism behaviorally or sensually. In most of organizational cynicism researches related to general cynicism tendecy it is pointed out that sexuality does not affect cynicism. (Anderson \& Bateman 1997; Erdost et al. 2007; Efilti et al. 2008; Güzeller \& Kalağan 2008; James, 2005; Tokgöz \& Y1lmaz, 2008).

It is observed that average points of general cynicism inclinations do not differ greatly in cognitive, behavioral and sensual dimensions according to teachers' union membership variable. Hovewer, teachers' general cynicism inclinations of whom is a member of a union may be expected to be higher. These kind of unions must aim to help teachers to have a life of good quality and create a school environment where they can work much more efficiently (Acansoy, 2005). Workers are given the opportunity of being a union membership to protect their economic, social rights and freedom (Constitution, 1982). It is obvious that the main reason of union membership is to provide assistance in the name of problem solving and watch

Table 5.

Teachers' life satisfaction's prediction level of general cynicism inclinations' cognitive dimension.

\begin{tabular}{|c|c|c|c|c|c|}
\hline \multirow{2}{*}{$\begin{array}{l}\text { GENERAL } \\
\text { CYNICISM }\end{array}$} & \multirow[b]{2}{*}{$\mathrm{R}^{2}$} & \multirow[b]{2}{*}{$\mathrm{F}$} & \multirow[b]{2}{*}{$p$} & \multirow[b]{2}{*}{$\mathrm{t}$} & \multirow[b]{2}{*}{$p$} \\
\hline & & & & & \\
\hline $\begin{array}{c}\text { Life Satisfaction } \\
\text { (Independent Variable) }\end{array}$ & .031 & 12.31 & .000 & -3.558 & .000 \\
\hline \multicolumn{6}{|c|}{ Dependent Variable: Cognitive Dimension of General Cynicism } \\
\hline
\end{tabular}

Table 6.

Teachers' life satisfaction's prediction level of general cynicism inclinations' sensual dimension.

\begin{tabular}{|c|c|c|c|c|c|}
\hline \multirow{2}{*}{$\begin{array}{l}\text { GENERAL } \\
\text { CYNICISM }\end{array}$} & \multirow[b]{2}{*}{$\mathrm{R}^{2}$} & \multirow[b]{2}{*}{$\mathrm{F}$} & \multirow[b]{2}{*}{$p$} & \multirow[b]{2}{*}{$\mathrm{t}$} & \multirow[b]{2}{*}{$p$} \\
\hline & & & & & \\
\hline $\begin{array}{c}\text { Life Satisfaction } \\
\text { (Independent Variable) }\end{array}$ & .015 & 6.084 & .014 & -2.467 & .014 \\
\hline \multicolumn{6}{|c|}{ Dependent Variable: Sensual Dimension of General Cynicism } \\
\hline
\end{tabular}


the working place in an inquiring manner. Taking the inferences into consideration, teachers who have higher general cynicism inclinations may be expected to be member of a unioun.

It can be seen that average points of general cynicism inclinations do not differ greatly in cognitive, behavioral and sensual dimensions according to teachers' relationship status variable. Different research findings are (elde etmek) about the relationship between martial status and organizational cynicism. For instance, Kanter and Mirvis (1989) find out that people who are divorced or living apart from their partners have higher cynicism levels than married or single ones. Efilti et al. (2008) and Erdost et al. (2007) can not find a correlation between martial status and cynicism.

It is observed that there is meaningful but in a negative way corelation between life satisfaction points and conginitive, sensual dimensions of general cynicism inclinations. However, no meaningful correlation can be found between teachers' life satisfaction points and behavioral dimension points of general cynicism inclinations. Teachers' life satisfaction explains $3.1 \%$ of the variability in cognitive dimension and $1.5 \%$ of the variability in sensual dimension of general cynicism inclinations. The act of meeting teachers' expectations related with life can help to reduce their cynic thoughts, emotions and behaviors. Veenhoven (1996) defined life satisfaction as positive improvement degree of life quality as a whole. The emergence of negative way related between life satisfaction and general cynicism inclinations can be expected due to the positive perception of development in a person's each part of life.

\section{REFERENCES}

Acansoy, U. (2005). Yönetim öğretmeni sendika üyesi olma konusunda rahatlatmali. Yeni Ĕgitim, 3, 12.

Arslan, E. T. (2012). Süleyman demirel üniversitesi iktisadi ve idari bilimler fakültesi akademik personelinin genel ve örgütsel sinizm düzeyi. Doğuş Üniversitesi Dergisi, 13, 12-27.

Balcı, A. (2004). Sosyal bilimlerde araştirma. Ankara: Pegem Yayıncllik.

Christopher, J. C. (1999). Situating psychological well-being: Exploring the cultural roots of its theory and research. Journal of Counseling \& Development, 77, 141-153. doi:10.1002/j.1556-6676.1999.tb02434.x

Diener, E., \& Diener, M. (1995). Cross-cultural correlates of life satisfaction and self-esteem. Journal of Personality and Social Psychology, 68, 653-663. doi:10.1037/0022-3514.68.4.653

Diener, E., Emmons, R. A., Larsen, R. J., \& Griffin, S. (1995). The satisfaction with life scale. Journal of Personality Assessment, 49, 71-75. doi:10.1207/s15327752jpa4901 13

Efilti, S., Gönen, Y., \& Öztürk, F. (2008). Örgütsel sinizm: Akdeniz üniversitesinde görev yapan yönetici sekreterleri üzerinde bir alan araştirmasi. Ulusal büro yönetimi ve sekreterlik kongresi (pp. 1-14). Trabzon: Karadeniz Teknik Üniversitesi.

Erdost, H. E., Karacaoğlu, K., \& Reyhanoğlu, M. (2007). Örgütsel sinizm kavrami ve ilgili ölçeklerin türkiye'deki bir firmada test edil- mesi. Ulusal yönetim ve organizasyon kongresi bildiriler kitabi (pp. 514-524). Sakarya: Sakarya Üniversitesi.

Güzeller, C. O., \& ve Kalağan, G. (2008). Örgütsel sinizm ölçeğinin türkçeye uyarlamasi ve çeşitli değişkenler açisindan eğitim örgütlerinde incelenmesi. Yönetim ve organizasyon kongresi bildiriler kitabi (pp. 87-94). Antalya: İstanbul Kültür Üniversitesi.

Helvac1, M. A. (2010). Örgütsel sinizm. Yönetimde yeni yaklaşimlar. In H. B. Memduhoğlu ve K. Yılmaz (Eds.), Ankara: Pegem Akademi Yayınları.

İnce, M., \& Turan, S. (2011). Organizational cynicism as a factor that affects the organizational change in the process of globalization and an application in Karaman's public institutions. European Journal of Economics, Finance and Administrative Sciences, 37, 104-121.

James, M. S. L. (2005). Antecedents and consequences of cynicism in organizations: An examination of the potential positive and negative effects on school systems. Unpublished Doctoral Dissertation, Tallahassee: The Florida State University.

Kalağan, G., \& Ve Güzeller, C. O. (2010). Öğretmenlerin örgütsel sinizm düzeylerinin incelenmesi. Pamukkale Üniversitesi Eğitim Fakültesi Dergisi, 27, 83-97.

Kanter, D. L., \& Mirvis, P. H. (1989). The cynical Americans: Living and working in an age of discontent and disillusion. San Francisco: Jossey-Bass.

Köker, S. (1991). Normal ve sorunlu ergenlerin yaşam doyumu düzeylerinin karşılaştırılması. (yayinlanmamiş yüksek lisans tezi). Ankara: A. Ü. Sosyal Bilimler Enstitüsü.

Özer, M., \& Karabulut, Ö. Ö. (2003). Yaşlılarda yaşam doyumu. Geriatri, 6, 72-74.

Serin, N. G., \& Özbulak, B. (2006). Okul idarecilerinin duygusal zeka beceri düzeyleri ile yaşam doyumunu yönetcilik deneyimleri ve cinsiyet açısından incelenmesi. Uluslar arası Duygusal Zeka ve İletișim Sempozyum Bildiri Kitabı, İzmir Ege Üniversitesi, İletișim Fakültesi, ss. 23-30.

Sisman, M. (2002). Öğretmenlik Mesleğine Giriş. Ankara: Pegem A Yayıncilik.

Sünbül, A. M. (2002). Bir meslek olarak öğretmenlik. Öğretmenlik mesleğine giriş. Ankara: Pegem Yayıncılık.

Sung-Mook, H. and Giannakopoulos, E. (1994). The relationship of satisfaction with life to personality characteristics. Journal of Psychology Interdisciplinary \& Applied, 128, 547. doi: $10.1080 / 00223980.1994 .9914912$

Temel, Z. F., \& Aksoy, A. B. (2001). Ergen ve gelişimi: Yetişkinliğe ilk adim. Ankara: Nobel Yayın Dağıtım.

Tokgöz, N. (2011). Örgütsel sinisizm, örgütsel destek ve örgütsel adalet ilişkisi: Elektrik dağitim işletmesi çalişanlari örneği. Eskişehir Osmangazi Üniversitesi İ̈BF Dergisi, 6, 363-387.

Tokgöz, N., \& Yılmaz, H. (2008). Örgütsel sinizm: Eskișehir ve Alanya'daki otel işletmelerinde bir uygulama. Anadolu Üniversitesi Sosyal Bilimler Dergisi, 8, 238-305.

Vara, Ş. (1999). Yoğun bakim hemşirelerinde iş doyumu ve genel yaşam doyumu arasindaki ilişsilerin incelenmesi. Yayınlanmamış yüksek lisan tezi. İzmir: E. Ü. Sağlık Bilimleri Enstitüsü.

Veenhoven, R. (1996). The study of life satisfaction. In: W. E. Saris, R. Veenhoven, A. C. Scherpenzeel, \& B. Bunting (Eds). A comparative study of satisfaction with life in Europe (pp. 11-48). Budapest: Eötvös University Press.

Yetim, Ü. (2001). Toplumdan bireye mutluluk resimleri. Istanbul: Bağlam Yayinlari. 